\title{
Anesthetic induction of juveniles of Rhamdia quelen and Ctenopharyngodon idella with Ocimum micranthum essential oil
}

\author{
Carla Cristina Zeppenfeld ${ }^{1}$ Marisa Teresinha de Bastos Brasil ${ }^{2}$ Gisela Cavalcante $^{3}$ \\ Lenise Vargas Flôres da Silva ${ }^{3}$ Rosa Helena Mourão ${ }^{4}$ \\ Mauro Alves da Cunha ${ }^{1,2}$ Bernardo Baldisserotto ${ }^{1,2^{*}}$ iD
}

${ }^{1}$ Departamento de Fisiologia e Farmacologia, Universidade Federal de Santa Maria (UFSM), 97105-900, Santa Maria, RS, Brasil. E-mail: bbaldisserotto@hotmail.com. *Corresponding author.

${ }^{2}$ Programa de Pós-graduação em Zootecnia, Universidade Federal de Santa Maria (UFSM), Santa Maria, RS, Brasil. ${ }^{3}$ Instituto de Ciências e Tecnologia das Águas, Universidade Federal do Oeste do Pará (UFOPA), Santarém, PA, Brasil.

${ }^{4}$ Programa de Pós-graduação em Recursos Naturais da Amazônia, Laboratório de Bioprospecção e Biologia Experimental, Universidade Federal do Oeste do Pará (UFOPA), Santarém, PA, Brasil.

\begin{abstract}
Anesthetics are effective to reduce or minimize stress in handling operations related to fish cultures. Aiming to avoid residual effects of synthetic drugs, several natural agents, such as essential oils (EOs), have been tested. The aim of this study was to determine the optimal concentration of the EO of Ocimum micranthum for induction of anesthesia in juveniles of silver catfish (Rhamdia quelen) and grass carp (Ctenopharyngodon idella). Results demonstrated that the most suitable concentration to sedate silver catfish and carp is $25 \mu L / L$, while to anesthetize $200 \mu \mathrm{L} / \mathrm{L}$ is more suitable for silver catfish and $100 \mu \mathrm{L} / \mathrm{L}$ for grass carp, because these concentrations induce deep anesthesia in less than three min and recovery in less than five min. Analysis of the EO constituents showed methyl chavicol, a compound with carcinogenic potential, as the major component (58.2\%). Therefore, the EO of O. micranthum is not recommended for fish anesthesia if the fish are to be used as food.
\end{abstract}

Key words: anesthesia, silver catfish, grass carp, sedation.

\section{Indução anestésica de Rhamdia quelen e Ctenopharyngodon idella com o óleo} essencial de Ocimum micranthum

RESUMO: Os anestésicos são eficazes para reduzir ou minimizar o estresse nas operações de manuseio relacionadas à piscicultura. Com o objetivo de evitar efeitos residuais de fármacos sintéticos, vários agentes naturais, como óleos essenciais (OEs), têm sido testados. O objetivo deste estudo foi determinar a concentração ótima do OE de Ocimum micranthum para a indução de anestesia em juvenis de jundiá (Rhamdia quelen) e carpa capim (Ctenopharyngodon idella). Os resultados demonstram que a concentração mais adequada para sedar jundiás e carpas capim é $25 \mu \mathrm{L} / \mathrm{L}$. Enquanto que para anestesiar $200 \mu \mathrm{L} / \mathrm{L}$ é mais adequado para jundiás e 100 $\mu$ L/L para carpas capim, pois essas concentrações induzem anestesia profunda em menos de três minutos e recuperação em menos de cinco minutos. A análise dos constituintes do OE identificou o metil chavicol, um composto com potencial carcinogênico, como componente majoritário (58,2\%). Portanto, o OE de O. micranthum não é recomendado para anestesia de peixes usado como alimento.

Palavras-chave: anestesia, jundiá, carpa-capim, sedação.

\section{INTRODUCTION}

Anesthetics have been used in aquaculture to minimize the stress that occurs in fish management operations, but some may cause adverse effects on fish, manipulators or in the environment. The choice of an anesthetic also depends on availability, cost, ease use and physical state (CHO \& HEATH, 2000). Several substances and combinations of substances, such as alcohol, ether, barbiturates, quinaldine, tricaine methanesulfonate (MS 222), chlorbutanol and benzocaine have been used to induce anesthesia in fish. However, each of these agents has been associated with undesirable systemic side effects and limited safety margins to the extent that their use has either been limited or rejected altogether (GILDERHUS \& MARKING, 1987; PALIĆ et al., 2006). Consequently, there is a search for natural anesthetics with little or no toxicity and low cost. 
Some essential oils (EOs), such as those from Lippia alba (chemotype linalool) and Aloysia triphylla, are efficacious to anesthetize fish, not aversive and have almost no side effects (BANDEIRA JUNIOR et al., 2018; PARODI et al., 2014; SOUZA et al., 2017; ZEPPENFELD et al., 2014). However, in zebrafish, Danio rerio, the EO of A. triphylla was stressful and did not attenuate cortisol increase after stress (BANDEIRA JUNIOR et al., 2018). The EO of plants from the genus Ocimum also have presented anesthetic activity (BENOVIT et al., 2012).

Ocimum micranthum (Lamiaceae), an herb native of Central Lowlands, South America and West Indies, is used locally to flavor beverages and soups, and for the treatment of fever, stomach disturbances and dysentery. A decoction of the plant is also used for nervous disorders, earaches, colic and convulsions in children, as well as for painful menstruation (LINO et al., 2005). Therefore, the aim of this study was to determine the anesthetic effect of another species of this genus, Ocimum micranthum, in two fish species: Rhamdia quelen (silver catfish) and Ctenopharyngodon idella (grass carp).

\section{MATERIALS AND METHODS}

\section{Fish and culture conditions}

Experiments were conducted in the Fish Physiology Laboratory at the Universidade Federal de Santa Maria (UFSM), Rio Grande do Sul state (RS), Brazil. Juvenile silver catfish (Rhamdia quelen) and grass carp (Ctenopharyngodon idella) with average weights of $10.14 \pm 0.70 \mathrm{~g}$ and $7.20 \pm 0.33 \mathrm{~g}$, respectively, were obtained from a local supplier and kept for one week for acclimation in 250L tanks. The fish were given a diet of commercial feed with $28.0 \%$ crude protein ZEPPENFELD et al. (2014). Juveniles were fed once a day, at 8:00 a.m. at a ratio of $5.0 \%$ body mass. Juveniles were fasted for a period of $24 \mathrm{~h}$ prior to experiments. Water parameters were checked daily (temperature, $\mathrm{pH}$ and dissolved oxygen) or weekly (alkalinity, hardness, total ammonia and nitrite) as described by ZEPPENFELD et al., (2014). Water parameters remained stable and in the desired range throughout the experimental period. Temperature was maintained at $23.20 \pm 0.20^{\circ} \mathrm{C}, \mathrm{pH}$ at $7.00 \pm 0.01$, dissolved oxygen at $6.50 \pm 0.40 \mathrm{mg} / \mathrm{L}$, hardness at $23.0 \pm 1.7 \mathrm{mg}$ $\mathrm{CaCO}_{3} / \mathrm{L}$, alkalinity at $41.0 \pm 0.7 \mathrm{mg} \mathrm{CaCO}_{3} / \mathrm{L}$, nitrite at $0.05 \pm 0.01 \mathrm{mg} / \mathrm{L}$, total ammonia at $0.81 \pm 0.60 \mathrm{mg} / \mathrm{L}$ and non-ionized ammonia at $0.0053 \pm 0.0500 \mathrm{mg} / \mathrm{L}$.

\section{Plant material and essential oil extraction}

EO analysis was performed on a GCMS-

QP2010 Ultra system (Shimadzu Corporation,
Tokyo, Japan) equipped with an AOC-20i autoinjector and the GCMS-Solution software containing the Adams, NIST11 and FFNSC2 libraries. Rxi$5 \mathrm{~ms}(30 \mathrm{mx} 0.25 \mathrm{~mm} ; 0.25 \mu \mathrm{m}$ film thickness) silica capillary column (Restek Corporation, Bellefonte, PA, USA) was used. Conditions of analysis were: injector temperature of $250^{\circ} \mathrm{C}$; oven temperature programming of $60-240^{\circ} \mathrm{C}\left(3^{\circ} \mathrm{C} / \mathrm{min}\right)$; helium as carrier gas, adjusted at a linear velocity of $36.5 \mathrm{~cm} / \mathrm{s}$ (rate of $1.0 \mathrm{~mL} / \mathrm{min}$ ); injection in the split mode of $1 \mu \mathrm{l}$ of the sample $(2 \mu \mathrm{L}$ of the essential oil in $500 \mu \mathrm{L}$ of hexane); split ratio 1:20; ionization by electronic impact at $70 \mathrm{eV}$; ionization source and transfer line temperatures of $200^{\circ} \mathrm{C}$ and $250^{\circ} \mathrm{C}$, respectively. Mass spectra were obtained by automatic scanning every $0.3 \mathrm{~s}$, with mass fragments in the range of $35-400 \mathrm{~m} /$ z. Retention index was calculated for all volatile components using a homologous series of C8-C20 n-alkanes (Sigma-Aldrich), according to the linear equation of VAN DEN DOOL and KRATZ (1963). Quantitative data regarding the volatile constituents were obtained by peak-area normalization using a Shimadzu GC 2010 Ultra system, coupled to FID Detector, operated under similar conditions as the GC-MS system except nitrogen was used as carrier gas. Constituents were identified by comparing their retention indices and mass spectra (molecular mass and fragmentation pattern) with those existing in the GCMS-Solution system libraries, and also with spectra from literature (ADAMS, 2007).

\section{Anesthesia induction and recovery}

After the acclimation period, fish were transferred to tanks containing $1 \mathrm{~L}$ of water and EO of $O$. micranthum at concentrations of 25, 50, 100, 200 and $300 \mu \mathrm{L} / \mathrm{L}$, previously dissolved in ethanol [1:10]. Grass carp were also exposed to the highest concentration of ethanol used to dilute the EO. This ethanol concentration did not have any sedative or anesthetic effect in silver catfish (SOUZA et al., 2017). Ten fish were used to evaluate anesthetic induction times in each concentration, each fish being used only once. Induction of anesthesia was evaluated according to an adaptation of the stages described in SMALL (2003): Stage 1 - sedation (decreased response to external stimuli), Stage 2 slight anesthesia (partial loss of equilibrium; erratic swimming) and Stage 3 - deep anesthesia (total loss of equilibrium and no reaction to caudal peduncle pressure). Maximum observation time was $30 \mathrm{~min}$. After the induction tests, fish were transferred to anesthetic free aquaria for checking recovery time. Fish were considered recovered when they presented 
normal swimming behavior and were responsiveness to external stimuli.

\section{Statistical analyses}

To verify the homogeneity of variances, all data were submitted to Levene's test. Evaluation of anesthetic activity was performed by regression analysis (concentration of the $\mathrm{EO} \times$ time to induce sedation, slight and deep anesthesia, or recovery) using the Sigma Plot 11.0 software. When no significant relationship was reported, concentrations were compared by one-way ANOVA followed by Tukey's post hoc test using the Statistica software 7.0. Differences were considered significant at $\mathrm{P}<0.05$. Data are presented as the mean \pm SEM.

\section{RESULTS}

The major components of EO Ocimum micranthum were determined to be methyl chavicol $(58.2 \%)$ and linalool $(29.8 \%)$.

The increased EO concentrations of $O$. micranthum proportionally decreased the time required for light and deep anesthesia in silverfish and carp. Time to induce sedation also decreased at higher concentrations, but the relationship was significant only for grass carp. No significant relationship was observed between concentration and time required for recovery in both species. Fish of both species submitted to $25 \mu \mathrm{L} / \mathrm{L}$ did not reach the slight or deep anesthesia stages during the $30 \mathrm{~min}$. observation. Silver catfish exposed $50 \mu \mathrm{L} / \mathrm{L}$ EO $O$. micranthum showed slower recovery than those exposed to 100 and $200 \mu \mathrm{L} / \mathrm{L}$ (Table 1). However, grass carp exposed to $50 \mu \mathrm{L} / \mathrm{L}$ presented faster recovery than those exposed to 100 and $200 \mu \mathrm{L} / \mathrm{L}$ (Table 2). Ethanol did not provoke any sedative or anesthetic effect in grass carps. There was no mortality during the trial period.

\section{DISCUSSION}

Methylchavicol and linalool are the main compounds of the EO of O. micranthum. Similar results were reported by OLIVEIRA et al. (2013). Methylchavicol, or estragole, is a natural constituent of a number of plants, including tarragon (Artemisia dracunculus), sweet basil (Ocimum canum) and sweet fennel (Pimpinella anisum), and their EOs have been widely used in foodstuffs as flavoring agents (VINCENZI et al., 2000).

The efficacy of a fish anesthetic depends on short latency time (approximately three min.) and rapid recovery of the fish (approximately five min.) (MARKING \& MEYER, 1985). The recommended concentrations for deep anesthesia are $200 \mu \mathrm{L} / \mathrm{L}$ for silver catfish and $100 \mu \mathrm{L} / \mathrm{L}$ for grass carp, because they induce deep anesthesia in less than three min and recovery in less than five min. However, to maintain the fish only sedated (Stage 1) for a long period, as in fish transport for some hours, the concentration indicated is $25 \mu \mathrm{L} / \mathrm{L}$ for both species.

Similar results for anesthetic induction of silver catfish were found using other EOs, such as of Lippia alba, chemotype linalool (300mg/L) (CUNHA et al., 2010). Linalool, one of the main compounds of the EO of O. micranthum, was used in Cyprinus carpio $\left(753 \mu \mathrm{LL}^{-1} \mathrm{~L}\right)$ to induce deep anesthesia within three min (MIRGHAED et al., 2016).

Table 1 - Relationship between the essential oil concentration of Ocimum micranthum and the time required to reach each stage of anesthetic induction and recovery in Rhamdia quelen. $\mathrm{x}=$ concentration of essential oil $(\mu \mathrm{L} / \mathrm{L})$; $\mathrm{y}=$ time required for the stages of anesthetic induction in seconds. Different letters in the column "Recovery" indicate significant difference between concentrations. Evaluation of anesthetic activity was performed by regression analysis (concentration of the EO x time to induce sedation, slight and deep anesthesia, or recovery). When no significant relationship was reported, concentrations were compared by one-way ANOVA followed by Tukey's post hoc test. Differences were considered significant at $\mathrm{P}<0.05$. Data are presented as the mean \pm SEM.

\begin{tabular}{|c|c|c|c|c|}
\hline & Sedation & Slightanesthesia & Deepanesthesia & Recovery \\
\hline $25 \mu \mathrm{L} / \mathrm{L}$ & $163.30 \pm 13.79^{\mathrm{a}}$ & - & - & - \\
\hline $50 \mu \mathrm{L} / \mathrm{L}$ & $121.60 \pm 11.39^{\mathrm{a}}$ & $483.33 \pm 8.49$ & $1361.20 \pm 97.36$ & $227.50 \pm 7.20^{\mathrm{a}}$ \\
\hline $100 \mu \mathrm{L} / \mathrm{L}$ & $50.90 \pm 4.84^{\mathrm{b}}$ & $182.80 \pm 12.82$ & $686.80 \pm 92.51$ & $82.89 \pm 19.49^{b}$ \\
\hline $200 \mu \mathrm{L} / \mathrm{L}$ & $42.45 \pm 1.63^{\mathrm{b}}$ & $60.00 \pm 2.53$ & $89.73 \pm 4.03$ & $92.09 \pm 10.01^{\mathrm{b}}$ \\
\hline \multirow[t]{3}{*}{$300 \mu \mathrm{L} / \mathrm{L}$} & $42.89 \pm 1.16^{\mathrm{b}}$ & $68.70 \pm 4.27$ & $119.20 \pm 9.64$ & $200.70 \pm 22.47^{\mathrm{ab}}$ \\
\hline & \multicolumn{2}{|c|}{------------------y=-52.0+(26077.48/x)--------------- } & \multicolumn{2}{|c|}{------------------------y=211.023+(78964.55/x)---------------------- } \\
\hline & \multicolumn{2}{|c|}{ 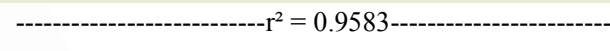 } & ----------------------1 & ----------------- \\
\hline
\end{tabular}

Ciência Rural, v.49, n.1, 2019. 
Table 2 - Relationship between the essential oil concentration of Ocimum micranthum and the time required to reach each stage of anesthetic induction and recovery in Ctenopharyngodon idella. $\mathrm{x}=$ concentration of essential oil $(\mu \mathrm{L} / \mathrm{L})$; $\mathrm{y}=$ time required for the stages of anesthetic induction in seconds. Different letters in the column "Recovery" indicated significant difference between concentrations. Evaluation of anesthetic activity was performed by regression analysis (concentration of the EO $\mathrm{x}$ time to induce sedation, slight and deep anesthesia, or recovery). When no significant relationship was reported, concentrations were compared by one-way ANOVA followed by Tukey's post hoc test. Differences were considered significant at $\mathrm{P}<0.05$. Data are presented as the mean \pm SEM.

\begin{tabular}{|c|c|c|c|c|}
\hline \multirow{2}{*}{$25 \mu \mathrm{L} / \mathrm{L}$} & Sedation & Slightanesthesia & Deepanesthesia & Recovery \\
\hline & $903.60 \pm 76.98$ & - & - & - \\
\hline $50 \mu \mathrm{L} / \mathrm{L}$ & $147.44 \pm 11.61$ & $324.10 \pm 21.09$ & $704.80 \pm 58.2$ & $40.56 \pm 4.96^{\mathrm{a}}$ \\
\hline $100 \mu \mathrm{L} / \mathrm{L}$ & $60.70 \pm 2.43$ & $121.40 \pm 3.95$ & $108.44 \pm 8.82$ & $67.80 \pm 4.99^{\mathrm{ab}}$ \\
\hline $200 \mu \mathrm{L} / \mathrm{L}$ & $51.90 \pm 2.46$ & $97.70 \pm 3.55$ & $114.06 \pm 4.11$ & $142.50 \pm 10.03^{\mathrm{b}}$ \\
\hline $300 \mu \mathrm{L} / \mathrm{L}$ & $41.40 \pm 1.55$ & $68.44 \pm 1.89$ & $103.40 \pm 3.38$ & $162.90 \pm 14.84^{\mathrm{b}}$ \\
\hline \multicolumn{2}{|c|}{--------y=-124.5405+(23352.7995/x)-------- } & $-----y=15.7675+(14353.8272 / x)-----$ & \multicolumn{2}{|c|}{-------------y=-387.3652+(96399.7606/x----------- } \\
\hline \multicolumn{2}{|c|}{---------------------rrene.8083------------------ } & 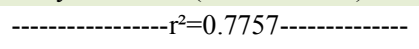 & \multicolumn{2}{|c|}{ - } \\
\hline
\end{tabular}

The EO of $O$. micranthum has demonstrated anti-nociceptive effects in mice, and pretreatment with naloxone did not reverse the anti-nociception, indicating that the opioid system is not involved (LINO et al., 2005). Estragole (methylchavicol) presents some controversial results regarding its mutagenicity and carcinogenic effect. However, the formation of hepatic DNA adducts in vivo and in vitro by metabolites of estragole has been demonstrated (VINCENZI et al., 2000). The authors reported that in order to better assess the risk associated with exposure to estragole long-term carcinogenicity studies and a wide range of dose levels are needed.

\section{CONCLUSION}

The EO of $O$. micranthum leaves could be considered an effective anesthetic for silver catfish and grass carp, since induction and recovery occur rapidly and safely without causing mortality to fish. However, analysis of the EO constituents showed the presence of estragole (methylchavicol) as one of the major components and this compound has carcinogenic potential. Therefore, the EO of $O$. micranthum is not recommended for fish anesthesia.

\section{ACKNOWLEDGMENTS}

The authors thank Conselho Nacional de Desenvolvimento Científico e Tecnológico (CNPq), Brazil, process for financial support Bernardo Baldisseroto, process 302076/2017-4 for financial support of Mauro Alves da Cunha and Marisa Teresinha de Bastos Brasil. Carla Cristina Zeppenfeld received a support of Coordenação de Aperfeiçoamento de Pessoal de Nível Superior (CAPES). This study was financed in part by the
Coordenação de Aperfeiçoamento de Pessoal de Nível Superior Brasil (CAPES) - Finance Code 001

\section{COMMITTEE ON ETHICS AND BIOSAFETY}

The experimental protocol was approved by the Ethical and Animal Welfare Committee of the Universidade Federal de Santa Maria (UFSM) under registration n 74/2014.

\section{DECLARATION \\ OF \\ CONFLICTING INTERESTS}

The authors declare no conflict of interest. The founding sponsors had no role in the design of the study; in the collection, analyses, or interpretation of data; in the writing of the manuscript, and in the decision to publish the results.

\section{AUTHORS' CONTRIBUTIONS}

Carla C. Zeppenfeld, Mauro A. Cunha, and Bernardo Baldisserotto designed the experiments. Carla C. Zeppenfeld and Gisela Cavalcante carried out the experiments. Carla C. Zeppenfeld and Mauro A. Cunha performed the statistical analysis of experimental data. Lenise V.F. Silva and Rosa H. Mourão provided the essential oil its chromatography analysis. Carla C. Zeppenfeld, Mauro A. Cunha and Bernardo Baldisserotto wrote the manuscript. All authors critically reviewed the manuscript and approved the final version.

\section{REFERENCES}

ADAMS, P. Identification of essential oil components by gas chromatography/mass spectrometry, 4ed. Allured Publishing, Carol Stream, IL, 2007.

BANDEIRA JUNIOR, G. et al. Lippia alba and Aloysia triphylla essential oils are anxiolytic without inducing aversiveness in fish. Aquaculture, 482, 49-56, 2018. Available from: <https://www. sciencedirect.com/science/article/pii/S0044848617307676>. Accessed: Mar. 14, 2018. doi: 10.1016/j.aquaculture.2017.09.023. 
BENOVIT, S.C. et al. Anesthesia and transport of Brazilian flounder, Paralichthys orbignyanus, with essential oils of Aloysia gratissima and Ocimum gratissimum. Journal World Aquaculture Society, 43: 896-900, 2012. Available from: <http://onlinelibrary.wiley.com/ doi/10.1111/j.1749-7345.2012.00604.x/full>. Accessed: Mar. 10, 2018. doi: 10.1111 / j.1749-7345.2012. 00604.x.

CHO, G. K.; HEATH, D.D. Comparison of tricainemethanesulphonate (MS222) and clove oil anaesthesia effects on physiology of juvenile chinook salmon Oncorhynchus tshawytscha (Watbaum). Aquaculture Research, v.31, p.537-546,2000. Available from: $<$ http://onlinelibrary. wiley.com/doi/10.1046/j.1365-2109.2000.00478.x/full>. Accessed: Mar. 10, 2018. doi: $10.1046 /$ j.1365-2109.2000.00478.x.

CUNHA, M. A.et al. Anesthesia of silver catfish with eugenol: time of induction, cortisol response and sensory analysis of fillet. Ciência Rural, v40: 2107-2114, 2010. Available from: <http://www.scielo.br/ scielo.php?script=sci_arttext\&pid=S0103-84782010001000009 $>$. Accessed: Mar. 14, 2018. doi: 10.1590/S0103-84782010005000154.

GILDERHUS, P.A. \& MARKING, L.L. Comparative efficacy of 16 anesthetic chemicals on rainbow trout. North American Journal of Fisheries Management, 7, 288-292, 1987. Available from: <https:// www.tandfonline.com/doi/abs/10.1577/15488659\%281987\%297 \%3C288\%3ACEOACO $\% 3 \mathrm{E} 2.0 . \mathrm{CO} \% 3 \mathrm{~B} 2>$. Accessed: Mar. 10, 2018. doi: $10.1577 / 1548-8659(1987) 7<288$ :CEOACO $>2.0 . C O ; 2$.

LINO, C. S., et al., Evaluation of antinociceptive and antiinflammatory activities of the essential oil (EO) of Ocimum micranthum Willd. From Northeastern Brazil. Phytotherapy Research, v19, p.708-712, 2005. Available from: <http:// onlinelibrary.wiley.com/doi/10.1002/ptr.1737/abstract $>$. Accessed: Mar. 09, 2018. doi: 10.1002/ptr.1737.

MARKING, L.L.; MEYER, F.P. Are better fish anesthetics needed in fisheries? Fisheries, v10, n6, p.2-5, 1985. Available from: $<$ https://www. tandfonline.com/doi/abs/10.1577/1548-8446\%281985\%29010\%3C0 002\%3AABANIF\%3E2.0.CO\%3B2>. Accessed: Mar. 09, 2018. doi: 10.1577/1548-8446(1985)010<0002:ABANIF $>2.0 . C O ; 2$

MIRGHAED, A.T.; et al. Myrcene and linalool as new anesthetic and sedative agents in common carp, Cyprinus carpio Comparison with eugenol. Aquaculture, v.464, p.165-170, 2016. Available from: <https://www.sciencedirect.com/science/article/ pii/S0044848616303325?via\%3Dihub>. Accessed: Mar. 14, 2018. doi: 10.1016/j.aquaculture.2016.06.028.

OLIVEIRA, R.A. de, MOREIRA, I.S.; OLIVEIRA, F.F. Linalool and methyl chavicol present basil (Ocimum sp.) cultivated in Brazil. Revista Brasileira de Plantas Medicinais, v.15, n.2, p.309-311, 2013. Available from: $<$ http://www.scielo.br/scielo.php?script=sci arttext\&pid $=$ S1516-05722013000200020 $>$. Accessed: Mar. 08, 2018. doi: 10.1590/S1516-05722013000200020.
PALIĆ, D. et al. Anesthetic efficacy of tricainemethanesulfonate, metomidate and eugenol: effects on plasma cortisol concentration and neutrophil function in fathead minnows (Pimephales promelas Rafinesque, 1820). Aquaculture, v254, p.675-685, 2006. Available from: <https://doi.org/10.1016/j.aquaculture.2005.11.004>. Accessed: Mar. 09, 2018. doi: 10.1016/j.aquaculture.2005.11.004.

PARODI, T. V. et al. Anesthetic activity of the essential oil of Aloysia triphylla and effectiveness in reducing stress during transport of albino and gray strains of silver catfish, Rhamdia quelen. Fish Physiology and Biochemistry, v40, 323-334, 2014. Available from: $<$ https://link.springer.com/article/10.1007\%2Fs10695-013-9845-z>. Accessed: Mar. 14, 2018. doi: 10.1007/s10695-013-9845-z.

SILVA, L.L. etal. Essential oil of Ocimum gratissimum L.: anesthetic effect, mechanism of action and tolerance in silver catfish. Rhamdia quelen. Aquaculture, v350-353, p.91-97, 2012. Available from: $<$ https://doi.org/10.1016/j.aquaculture.2012.04.012>. Accessed: Mar. 11, 2018. doi: 10.1016/j.aquaculture.2012.04.012.

SMALL, B.C., Anesthetic efficacy of metomidate and comparison of plasma cortisol responses to tricainemethanesulfonate, quinaldine and clove oil anesthetized channel catfish Ictalurus punctatus. Aquaculture, v218, p.177-185, 2003. Available from: $<$ https://www. sciencedirect.com/science/article/abs/pii/S0044848602003022>. Accessed: Mar. 10, 2018. doi: 10.1016/S0044-8486(02)00302-2.

SOUZA, C.F.Citral and linalool chemotypes of Lippia alba essential oil as anesthetics for fish: a detailed physiological analysis of side effects during anesthetic recovery in silver catfish (Rhamdia quelen). Fish Physiology and Biochemistry, v44, p.21-34, 2017. Available from: <https://link.springer.com/ article/10.1007\%2Fs10695-017-0410-z>. Accessed: Mar. 14, 2018. doi: $10.1007 / \mathrm{s} 10695-017-0410-\mathrm{z}$.

VAN DEN DOOL, H.; KRATZ, P.D.J.A., Generalization of the retention index system including linear temperature programmed gas-liquid partition chromatography. Journal of Chromatography A, v11, p.463-471, 1963. Available from: <https://www. sciencedirect.com/science/article/pii/S002196730180947X>. Accessed: Mar. 11, 2018. doi: 10.1016/S0021-9673(01)80947-X.

VINCENZI, M. et al. Constituents of aromatic plants: II. Estragole, Fitoterapia, v71. p.725-729. 2000. Available from: <https://www. sciencedirect.com/science/article/pii/S0367326X00001532>. Accessed: Mar. 14, 2018. doi: 10.1016/S0367-326X(00)00153-2.

ZEPPENFELD, C.C. et al. Physiological and biochemical responses of silver catfish, Rhamdia quelen, after transport in water with essential oil of Aloysia triphylla (L'Herit) Britton. Aquaculture, 418-419, 101-107, 2014. Available from: $<$ https:// doi.org/10.1016/j.aquaculture.2013.10.013>. Accessed: Mar. 10, 2018. doi: 10.1016/j.aquaculture.2013.10.01 